\title{
PRO MEMORIA — EMANUEL HALICZ (1921-2015)
}

Po 1968 roku wyjechało z Polski wielu historyków. Należy tu wymienić chociażby takie osoby jak: Lucjan Dobroszycki (1925-1995), Bolesław Drukier (1913-2006), Dawid Fajnhauz (1920-2004), Łukasz Hirszowicz (1920-1993), Henryk Katz (19141998), Paweł Korzec (1919-2012), Karol Lapter (1912-2003), Józef Lewandowski (1923-2007) czy Aleksander Litwin (1909-1984). W PRL oczywiście byli skazani na zapomnienie. W odróżnieniu od ich kolegów, którzy zdecydowali się nie wracać do Polski w 1945 roku, ich sytuacja była zupełnie inna. Nie wszyscy odnaleźli się w trudnych warunkach emigracyjnych. $Z$ racji swojego wcześniejszego zaangażowania w komunizm nie byli mile widziani przez „starą niezłomną emigrację”. Ostatnio odszedł jeden $\mathrm{z}$ ostatnich badaczy z tej grupy, wybitny badacz XIX wieku - Emanuel Halicz (1921-2015).

Historyk urodził się 19 września 1921 roku we Lwowie jako Emanuel Halpern jako syn Leona i Róży. Pochodził z rodziny polskich Żydów ${ }^{1}$. Od 1939 roku studiował na Wydziale Historycznym na ukraińskim uniwersytecie we Lwowie. Od 1940 roku był członkiem Komsomołu. W czerwcu 1941 roku został ewakuowany do Maryjskiej Autonomicznej Socjalistycznej Republiki Radzieckiej. Tam pracował jako nauczyciel.

Od października 1943 roku rozpoczął służbę w armii Z. Berlinga, jako oficer polityczny. Lata 1943-1945 spędził na bojowym szlaku od Oki po Łużyce. Wśród jego kolegów był m.in. Wojciech Jaruzelski. Działania wojenne ukończył w stopniu kapitana jako żołnierz 9 Drezdeńskiej Dywizji Piechoty (Halpern Emanuel, syn Leona). Co ciekawe w tej samej jednostce służyła osoba nazywająca się porucznik Emanuel Halicz. Emanuel Halpern zmienił nazwisko na Halicz w 1947 roku.

Po zakończeniu działań wojennych pozostał w armii. W latach 1947-1950 w stopniu podpułkownika był szefem Wydziału Propagandy Zarządu Politycznego Okręgu Wojskowego Kraków. Od kwietnia 1945 roku, co normalne w przypadku oficerów politycznych, był członkiem PPR, następnie kolejno PZPR. W 1947 roku nostryfikował dyplom ukończenia studiów na Uniwersytecie Jagiellońskim. Tam w 1950 roku obronił pracę doktorską Sprawa chłopska w powstaniu styczniowym pod kierunkiem Henryka Mościckiego (1881-1952).

W październiku 1950 roku Główny Zarząd Polityczny Wojska Polskiego skierował go na studia do Instytutu Kształcenia Kadr Naukowych (IKKN). Była to wyższa szkoła partyjna, powołana w 1950 roku przy Komitecie Centralnym PZPR. Jej zadaniem było kształcenie kierowniczych kadr naukowych w oparciu o wzorce nauki radzieckiej

\footnotetext{
${ }^{1}$ Materiały archiwalne dotyczące Emanuela Halicza znajdują się min. w Archiwum Akt Nowych - Akademia Nauk Społecznych, wyk 42/56 oraz w Centralnym Archiwum Wojskowym. Podstawowe informacje: Kto jest kim w Polsce, red. B. Cynkier, wyd. 4, Warszawa 2001, s. 292; T. Rutkowski, Nauki historyczne w Polsce 1944-1970. Zagadnienia polityczne i organizacyjne, Warszawa 2007; http://kulturaparyska.com/pl/ludzie/pokaz/e/emanuel_halicz?q=emanuel\%20halicz (dostęp: 20.06.2016).
} 
(Akademia Nauk społecznych przy KC WKP (b)). W ramach instytucji (łącznie siedem katedr) istniał Wydział Historii Polski, Historii Powszechnej i Historii WKP (b), kierowany przez osławioną Żannę Kormanową. W jego ramach powołano: Katedrę Historii Polski (kierownik - Stanisław Arnold, zastępcy: Żanna Kormanowa, Tadeusz Daniszewski), Katedrę Historii WKP(b) (kierownik - Józef Kowalski, zastępca Weronika Gostyńska) i Katedrę Historii Powszechnej (kierownik - Bronisław Krauze)². Poza S. Arnoldem, który miał dość pokaźny dorobek historyczny, wymienieni badacze byli po pierwsze działaczami partii, dopiero na drugim miejscu historykami. Nie przekreśla to oczywiście ich dorobku, w większości byli to historycy ruchu robotniczego. Pod ich kierunkiem w placówce zaczęły powstawać doktoraty - dla przykładu Mieczysław Rakowski był uczniem Bronisława Krauze. Aspiranci tej szkoły (obowiązywało nazewnictwo i wzory radzieckie) wywodzili się ze szkół i instancji partyjnych, instytucji państwowych, wojska, resortu bezpieczeństwa oraz z asystentury na wyższych uczelniach. Pierwszy rocznik liczył 78 osób. Główny Zarząd Polityczny WP razem z ppłk. E. Haliczem skierował rozkazem do szkoły też: ppłk. Bronisława Baczko, mjr Kazimierza Ochockiego, kpt. Zbigniewa Gaczyka.

W 1954 roku IKKN został przekształcony w Instytut Nauk Społecznych przy KC PZPR Pomimo ideologicznego statusu tej instytucji i krótkiego okresu działania do (1957 roku) przewinęło się przez nią wielu przyszłych wybitnych historyków. Kolegami Emanuela Halicza z roku byli: badacz dziejów starożytnych Roman Kamienik, mediewista Stanisław Piekarczyk, sinolog Wacław Rodziński czy historyk idei Bronisław Baczko ${ }^{3}$. W kolejnych latach przez szkołę przewinęli się też: Jan Borkowski, Marian M. Drozdowski, Karol Grünberg, Jerzy Holzer, Jan Kancewicz, Ryszard Kołodziejczyk, Marian Malinowski, Jan Molenda, Walentyna Najdus, Ryszard Nazarewicz, Henryk Słabek, Jerzy Tomaszewski, Maria Turlejska, Feliks Tych, Janusz Żarnowski, Marian Żychowski.

Od 1952 roku Emanuel Halicz był pracownikiem IKKN/INS, zatrudnionym na pół etatu. W 1954 r. uzyskał tam stopień kandydata nauk historycznych (ówczesna habilitacja; Kwestia chlopska w Królestwie Polskim na przetomie lat 50-60-tych XIX wieku). W 1954 r. został docentem. W INS pod kierunkiem E. Halicza w 1956 roku pracę doktorską Polityka czartoryszczyzny w okresie powstania 1863-1864 obroniła Irena Koberdowa (1916-2008). Jej postać zapisała się w polskiej historiografii jako badacz II połowy XIX wieku, a zwłaszcza ruchu robotniczego. W odróżnieniu od dużej grupy historyków ruchu robotniczego, pracujących w Zakładzie Historii Partii przy KC PZPR, Wyższej Szkole Nauk Społecznych czy Centralnym Archiwum PZPR, była minimalnie zaangażowana $\mathrm{w}$ działalność partyjną.

Praca $\mathrm{w}$ tej instytucji szkolnictwa partyjnego trwała dla młodego badacza jedynie do 1956 roku. Instytut Nauk Społecznych przy KC PZPR na przełomie 1956 i 1957 roku został zresztą rozwiązany, w jego miejsce utworzono Wyższą Szkołę Nauk Społecznych przy KC PZPR (1957). Tam też trafiła większość pracowników naukowych.

\footnotetext{
${ }^{2}$ B. Bińko, Instytut Ksztatcenia Kadr Naukowych przy KC PZPR - narzędzie ofensywy ideologicznej w nauce $i$ szkolnictwie wyższym, Kultura i Społeczeństwo 1996 nr 2, s. 199-214; T. Rutkowski, Nauki historyczne w Polsce 1944-1970. Zagadnienia polityczne i organizacyjne, Warszawa 2007, s. 319; J. Szumski, Polityka a historia: ZSRR wobec nauki historycznej w Polsce w latach 1945-1964, Warszawa 2016, s. 189-193.

${ }^{3}$ B. Bińko, Skad przychodzili, dokąd zmierzali... aspiranci pierwszego rocznika Instytutu Kształcenia Kadr Naukowych przy KC PZPR, [w:] Komunizm: ideologia, system, ludzie, red. T. Szarota, Warszawa 2001, s. 192-204.
} 
Poza pracą w tej uczelni, której monografii do niestety pory brak, historyk pracował jednocześnie na Uniwersytecie Warszawskim w latach 1952-1954 i 1960-1962. Jako wojskowy, w 1951 roku Halicz został członkiem Komisji Historyczno-Wojskowej MON. Zajmował się tam historią wojskowości okresu XVIII-XIX wieku. W tym okresie ukazały się jego pierwsze publikacje

Jednocześnie w latach 1954-1956 był członkiem komitetu redakcyjnego nieukazującego się już czasopisma „Studia i Materiały do Historii Wojskowości”4.

Trzeba jednak podkreślić, że płk. Emanuel Halicz ze względu na wiek nie odegrał jakiejś istotnej roli w stalinizacji nauki historycznej w Polsce. Będąc młodym pracownikiem naukowym instytucji partyjnych, mógł jedynie sekundować starszym kolegom historykom. Warto jednak zwrócić uwagę, że był uczestnikiem słynnej konferencji Otwockiej (28 XII 1951-12 I 1952).

Pułkownik, pozostający nadal do dyspozycji wojska w 1957 roku, mógł został skierowany do pracy w Wojskowym Instytucie Historycznym. Stało się jednak inaczej. Kolejnym miejscem pracy stała się Wojskowa Akademia Polityczna w Warszawie. Uczelnia istniejąca od 1951 roku. Pierwotnie jako Akademia Wojskowo-Polityczna. W czerwcu 1957 roku minister Obrony Narodowej zmienił jej nazwę na Wojskową Akademię Polityczną. Jej patronem był Feliks Dzierżyński. Jeżeli IKKN był wzorowany na Akademii Nauk Społecznych, to WAP był kopią Akademii im. W. Lenina w Moskwie. Kadra uczelni początkowo rekrutowała się wyłącznie z oficerów politycznych WP. W grudniu 1958 roku utworzono fakultet historyczny (później wydział). Szkoła kształciła słuchaczy początkowo na poziomie studiów magisterskich.

Halicz, pracujący na WAP, w chwili zatrudnienia był jednym z kilku wojskowych pracowników, posiadającym tytuł doktora ${ }^{5}$. Miejscem pracy był Wydział HistorycznoPolityczny. Dziekanem w latach 1957-1968 był zasłużony historyk dziejów nowożytnych - Janusz Woliński. Pułkownik dr E. Halicz w okresie 1958-1968 był kierownikiem Katedry Historii Polski ${ }^{6}$. Z jego katedrą byli związani też: Tadeusz Jędruszczak, Józef Lewandowski, Władysław Tomkiewicz, Maria Turlejska. Wobec braku wojskowej kadry WAP zatrudnił cywilnych historyków na co dzień pracujących na UW. Należy tu wymienić takie nazwiska jak: Stanisław Arnold, Ludwik Bazylow, Juliusz Bardach, Tadeusz Cieślak, Jerzy Dowiat, Stanisław Herbst, Karol Lapter, Marian Leczyk czy Andrzej Zahorski. W odróżnieniu od innych placówek nauki partyjnej (Wyższa Szkoła Nauk Społecznych), gdzie pracowali historycy, tu wykładali wybitni naukowcy. Efektem szeroko zakrojonych badań były wartościowe publikacje. Była to oczywiście zasługa zatrudnionych pracowników naukowych spoza wojska. W momencie, gdy Główny Zarząd Polityczny WP objął gen. W. Jaruzelski (1965), rozpoczął się proces usuwania cywilnych pracowników z WAP. Ostatecznie rok 1968 doprowadzi do zmiany większości kadry. Miejsce liczących się historyków z pokaźnym dorobkiem zajęli

${ }^{4}$ Wykaz członków Komitetu Redakcyjnego i Redakcji „Studiów i Materiałów do Historii Wojskowości" w latach 1954-1987, Studia i Materiały do Historii Wojskowości 1988, s. 40; T. M. Nowak, Z dziejów organizacji badań nad historia wojskowa w Polsce Ludowej, Studia i Materiały do Historii Wojskowości 1988, s. 19-42.

${ }^{5}$ A. Ciupiński, Wojskowa Akademia Polityczna im. F. Dzierżyńskiego 1951-1986, Warszawa 1986, s. 61; D. S. Kozerawski, Wyższe szkolnictwo wojskowe w Polsce w latach 1947-1967, Warszawa 2005, s. 295, przyp. 18.

${ }^{6}$ E. Horoszko, P. Kaczmarska, Wojskowa Akademia Polityczna im. Feliksa Dzierżyńskiego 1951-1990 w świetle akt Archiwum Ministerstwa Obrony Narodowej, Rocznik ArchiwalnoHistoryczny Centralnego Archiwum Wojskowego 2011 nr 4, s. 167-206; Zeszyty Naukowe WAP im. F. Dzierżyńskiego 1981, nr 107 (O historii i historykach w Wojskowej Akademii Politycznej). 
wojskowi, często niemający stopni naukowych. Co ciekawe w połowie lat 70.WAP uzyskał prawo do nadawania stopni naukowych doktora i doktora habilitowanego ${ }^{7}$.

Główne zainteresowania badawcze Halicza w tym czasie skupiały się na historii Polski i historii powszechnej XIX wieku. Historyk badał dzieje polskich powstań narodowych XIX wieku. Opublikował wiele opracowań na ten temat. Można bez przesady określić go - historykiem powstania styczniowego. Wraz z innymi historykami wchodził w skład komisji obchodów 100 rocznicy Powstania Styczniowego. W 1963 roku była bowiem obchodzona setna rocznica jego wybuchu. Historyk, jako ekspert w tej dziedzinie, był konsultantem filmu dokumentalnego Powstanie styczniowe z 1962 roku. Z kolei w latach 1956-1970 był członkiem komisji do wydania źródeł z okresu powstania styczniowego przy Polskiej Akademii Nauk i Akademii Nauk ZSRR ${ }^{8}$. Był też redaktorem wydawnictwa źródeł Naczelnej Dyrekcji Archiwów Państwowych edycji Proces Romualda Traugutta i członków Rządu Narodowego. Duże zasługi położył jako wydawca licznych tekstów źródłowych z okresu powstania styczniowego. Duże znaczenie mają zwłaszcza edycje pamiętników dokonane przez jego osobę. Temat insurekcyjny i sprawa polska w XIX wieku powracały w wielu publikacjach.

Swoje badania kierował też ku początkom XIX wieku. Ważna i do tej pory w pewnej mierze aktualna jest praca Geneza Księstwa Warszawskiego (Warszawa 1962). Pewnym szczególnym wydarzeniem była edycja broszury sekretarza Tadeusza Kościuszki - Józefa Pawlikowskiego - Czy Polacy wybić się moga na niepodległość? Halicz dołączył też do toczącej się od śmierci naczelnika dyskusji historyków o T. Kościuszce. Brał też czynny udział w dyskusji na temat ekranizacji Popiołów S. Żeromskiego w reżyserii A. Wajdy (1965). W odróżnieniu od części tzw. „historyków partyjnych" czy wojskowych kolegów z WAP, Emanuel Halicz publikował solidne źródłowo prace, a nie propagandowe broszury.

Kariera historyka rozwijała się szybko. W 1960 roku Halicz został profesorem nadzwyczajnym (pierwszy wojskowy w dziejach WAP). Był też członkiem: nowo powstałego Komitetu Nauk Historycznych PAN (1959-1966), członkiem komitetu wydawniczego Instytutu Historii PAN i Instytutu Słowianoznawstwa Akademii Nauk ZSRR, Komitetu Naukowego Obchodu Tysiąclecia Państwa Polskiego (1965-1966), Rady Głównej Szkolnictwa Wyższego (1963-1966) i Rady Wyższego Szkolnictwa Wojskowego (1963-1966). W 1965 roku badacz był członkiem kilkunastoosobowej delegacji polskiej na XII Międzynarodowy Kongres Nauk Historycznych w Wiedniu. Jako uznany badacz było recenzentem prac doktorskich powstałych na seminarium Stefana Kieniewicza w Instytucie Historycznym UW ${ }^{9}$. Sam Kieniewicz niewątpliwie cenił prace Halicza, o czym świadczą jego późniejsze recenzje jego prac ${ }^{10}$.

Będąc członkiem PZPR, dawnym pułkownikiem WP, cywilnym historykiem zajmującym się dziejami Powstania Styczniowego, profesorem WAP, zapewne nie spo-

\footnotetext{
${ }^{7}$ Szerzej o koncepcjach Jaruzelskiego na funkcjonowanie WAP zob.: L. Kowalski, Generat ze skaza. Biografia wojskowa gen. Armii Wojciecha Jaruzelskiego, Warszawa 2001, s. 225-228. W tej publikacji E. Halicz występuje w indeksie z imieniem Eugeniusz!

${ }^{8}$ W 1970 roku po usunięciu Halicza z Komisji zastąpiła go W. Śliwowska.

9 A. Grzybowski, Organizacja Miejska $w$ Warszawie $w$ okresie Powstania Styczniowego (1963); S. Król, X Pawilon Cytadeli Warszawskiej — główne więzienie polityczne Królestwa Polskiego w latach 1833-1856 (1965); F. Ramotowska, Rzad carski wobec ruchu narodowego w Królestwie Polskim w okresie manifestacji 1861-1862, (1966).

${ }^{10}$ Odmiennego zdania był Henryk Wereszycki; zob.: S. Kieniewicz, H. Wereszycki, Korespondencja z lat 1947-1990, wstęp i oprac. E. Orman, Kraków 2013, s. 679 (list Wereszyckiego do Kieniewicza z 30 września 1984).
} 
dziewał się nagłego załamania swojej kariery w Polsce Ludowej. Rok 1968 był w istocie dla niego i wielu innych katastrofą. Został usunięty z pracy w Wojskowej Akademii Politycznej.

Utrata pracy, a także nieprzychylny klimat spowodował, że nie widząc dla siebie perspektyw w PRL - Halicz postanowił emigrować. W 1971 roku wyemigrował z rodziną do Danii. W tym kraju znalazł się jego kolega Bolesław Drukier (w latach 19531957 prorektor INS, 1957-1968 prorektor WSNS), który wykładał na uniwersytecie w Roskilde. W pobliskiej Szwecji wykładali koledzy z WAP — Józef Lewandowski i Karol Lapter.

Już w 1972 roku został zdegradowany przez ministra obrony narodowej Wojciecha Jaruzelskiego do stopnia szeregowca. Stał się też obiektem zainteresowania służb specjalnych PRL ${ }^{11}$.

W latach 1972-1982 był profesorem uniwersytetu w Odense, a następnie w latach 1982-1990 uniwersytetu w Kopenhadze. Nadal pozostał aktywny zawodowo. W 1982 roku ukazała się jego ważna książka Polish National Liberation Struggle and the Genesis of the Modern Nation. Z okresu duńskiego pochodzi tez kilka innych ważnych publikacji. Wśród nich wyróżnia się praca Russia and Denmark 1856-1864. Dużej wielkości dzieło Halicza to owoc imponującej erudycji. Przyczyniło się na gruncie międzynarodowym do pogłębienia dziejów dyplomacji europejskiej omawianego ośmiolecia.

$\mathrm{Na}$ emigracji współpracował z paryskimi „Zeszytami Historycznymi”. Łącznie opublikował na łamach tego pisma 20 artykułów i recenzji, co plasuje go na 18 miejscu wśród autorów tego periodyku. Był też współpracownikiem pisma „Historisk Tidskrift”, „Zeitschrift für Ostmitteleuropa-Forschung” oraz „Zeitschrift für Ostforschung".

W 1989 roku został zaproszony przez Polską Akademię Nauk, Uniwersytet Jagielloński i Towarzystwo Polonia na III Kongres Uczonych Polskiego Pochodzenia odmówił jednak przyjazdu. Po zmianach w Polsce nawiązał też współpracę z „Przeglądem Historycznym”. W 1994 roku przywrócono mu utracony stopień wojskowy. Był odznaczony: Orderem Krzyża Grunwaldu (1945), Krzyżem Kawalerski Orderu Odrodzenia Polski (1946), Medalem za Odrę, Nysę, Bałtyk — (1956), Odznaką Tysiąclecia Państwa Polskiego (1966).

Odszedł historyk rzetelny i entuzjastyczne zaangażowany w badania historyczne, zabierając bezpowrotnie swe niewypowiedziane myśli, sugestie, propozycje rozwiązań, które mogłyby wzbogacić nasze postrzeganie przeszłości.

Michał Kozłowski (Lublin)

\footnotetext{
${ }^{11}$ IPN Ka 0024/28 t. $1-5$
} 


\section{Bibliografia ważniejszych prac prof. Emanuela Halicza}

\section{4}

Polska sztuka wojenna w okresie powstania styczniowego, Warszawa 1954.

1955

Kwestia chlopska w Królestwie Polskim w dobie powstania styczniowego, Warszawa 1955;

Rola nurtu plebejskiego $w$ polskich walkach narodowo-wyzwoleńczych $w$ latach 1794-1864, oprac. E. Halicz, M. Żychowski, Warszawa 1955.

\section{6}

Rola nurtu plebejskiego w polskich powstaniach narodowych XVIII i XIX wieku, oprac. E. Ha1957 licz, przy udziale M. Żychowskiego, Z. Mańkowskiego i W. Jakóbczyka, Warszawa 1956.

Optymizm czy pesymizm? Chłopstwo w walkach narodowowyzwoleńczych, Kwartalnik Historyczny 1957 z. 4/5, s. 136-141.

1958

Instrukcja powstańcza Ludwika Mierosławskiego, przyg. do druku E. Halicz, wstęp E. Halicz, Warszawa 1958.

1959

F. Kopernicki, Pamiętnik z powstania styczniowego: notatki z powstania $w$ województwie kaliskim 1863 i 1864 r., wstęp i przypisy E. Halicz, przyg. do druku E. Halicz, L. Ratajczyk, Warszawa 1959

1960

Proces Romualda Traugutta i czlonków Rządu Narodowego. Akta Audytoriatu Polowego z lat 1863/1864, t. 1-4, red. E. Halicz, Warszawa 1960-1961;

Tadeusz Kościuszko a pierwsza wojna polska (1806-1807), Zeszyty Naukowe Wojskowej Akademii Politycznej 1960 z. 2;

F. L. von Erlach, Partyzantka $w$ Polsce $w$ roku 1863. Na podstawie wtasnych obserwacji zbieranych na teatrze walki od marca do sierpnia, przyg. do druku E. Halicz, Warszawa 1960;

W. I. Nowacki-Kopaczyński, Pamiętnik Junoszy, oficera polskich żandarmów w powstaniu styczniowym, przyg. do druku E. Halicz, L. Ratajczyk, Warszawa 1960.

1961

Demokracja polska w powstaniu styczniowym: wybór źródel, red. E. Halicz, Wrocław 1961;

Nurty lewicowe $w$ dobie polskich powstań narodowych 1794-1849. Wybór źródet, pod red. E. Halicza, wstęp H. Jabłoński, Wrocław 1961.

\section{2}

La question polonaise a Tilsitt, Acta Poloniae Historica 1962, s. 45-65;

Sprawozdanie generała Edmunda Różyckiego z misji na Wschodzie w 1863/64 roku, Zeszyty Naukowe WAP. Seria Historyczna 1962 z. 7, s. 59-68.

1963

Koncepcje militarne powstania styczniowego i ich realizacja, Studia i Materiały do dziejów Wielkopolski i Pomorza 1963 z. 2, s. 6-22;

Korespondencja T. Berga z Aleksandrem II $w$ zwiazku z procesami politycznymi $w$ Królestwie Polskim w latach powstania styczniowego, Zeszyty Naukowe WAP, seria historyczna 1963 z. 9 (31), s. 105-112;

Marks o sprawie polskiej, Kwartalnik Historyczny 1963 z. 1, s. 116-120;

Od Wegrowa do Opatowa, Zeszyty Naukowe WAP. Seria historyczna 1963 z. 29, s. 136-141.

1964

U źródet dyktatury Romualda Traugutta, [w:] Z dziejów wojny i polityki. Ksiega pamiatkowa ku uczczeniu siedemdziesiątej rocznicy urodzin prof. dr Janusza Wolińskiego, Warszawa 1964, s. $54-61$.

\section{5}

Ksztaltowanie się ludowego charakteru Wojska Polskiego w latach drugiej wojny światowej, [w:] Z dziejów ludowego Wojska Polskiego, red. I. Pawłowski, Warszawa 1965, s. 26-41; 
J. Oxiński, Wspomnienia z powstania polskiego 1863-1864, oprac., wstęp i przypisy E. Halicz, Warszawa 1965

1966

W sprawie Nikiforowa, Zeszyty Naukowe WAP, seria historyczna 1965 z. 12, s. 76-80;

Katechizm demokratyczny polskich walk narodowowyzwoleńczych $w$ XIX wieku, Zeszyty Naukowe WAP. Seria Historyczna 1966 z. 14, s. 37-53.

1967

Rys ogólny działań władz rządowych w Królestwie Polskim za rok 1863, [w:] Studia Historyczne Stanisławowi Herbstowi na sześćdziesięciolecie urodzin w upominku uczniowie, koledzy, przyjaciele, red. J. Woliński, Warszawa 1967, s. 117-123;

Sprawa polska w świetle nassauskiego memoriatu Steina, [w:] Wiek XIX. Prace ofiarowane Stefanowi Kieniewiczowi w 60 rocznicę urodzin, red. B. Grochulska, B. Leśnodorski, A. Zahorski, Warszawa 1967, s. 126-132;

J. Pawlikowski, Czy Polacy wybić się moga na niepodległość, do druku przyg. i wstępem opatrzył E. Halicz, Warszawa 1967.

1968

Powstanie Styczniowe. Materialy i dokumenty, t. 1: Dokumenty Komitetu Centralnego Narodowego i Rzadu Narodowego 1862-1864, red. E. Halicz, S. Kieniewicz, I. Miller, Wrocław 1968 ;

Kościuszko i koleje historyczne tradycji kościuszkowskiej, Zeszyty Naukowe WAP, seria historyczna 1968 z. 18 (54).

1975

Partisan Warfare in 19th Century Poland: the Development of a Concept, transl. from the Polish 1980 by Jane Fraser, Odense 1975

Ksiądz Brzóska. Hierarchia kościelna a powstanie styczniowe, Zeszyty Historyczne 1980 z. 54, s. 40-58;

[Rec.] H.H. Henning, Aussenpolitik in der Emigration. Die Exildiplomatie Adam Jerzy Czartoryskis 1830-1840, München 1978, Historisk Tidsskrift 1980 z. 1, s. 259-260.

1981

[Rec.] H. Werner Rautenberg, Der polnische Aufstand von 1863 und die europäische Politik im Spiegel der deutschen Diplomatie und der öffentlichen Meinung, Wiesbaden 1979, Historisk Tidsskrift 1981 z. 1, s. 318-319;

[Rec.] Przemiany spoleczne w Królestwie Polskim 1815-1864, red. W. Kula i J. Leskiewiczowa, Wrocław 1979, Zeitschrift für Ostmitteleuropa-Forschung 1981 z. 3, s. 437-439;

[Rec.] F. Ramotowska, Rzad Narodowy Polski w latach 1863-1864. (Skład, organizacja, kancelaria), Łódź 1978, Zeitschrift für Ostmitteleuropa-Forschung 1981 z. 3, s. 441-444.

1982

[Rec.] N. Davies, God's Playground. A history of Poland, t. 1-2, New York 1982, Zeszyty Historyczne 1982, z. 60, s. 210-216;

[Rec.] N. Davies, God's Playground. A history of Poland, t. 1-2, New York 1982, Historisk Tidsskrift 1982 z. 2, s. 177-179;

Sprostowanie dot. notatki L. Muzyczki i K. Pluty-Czachowskiego (Zeszyty Historyczne Nr 60), Zeszyty Historyczne 1982 z. 60, s. 236.

1983

[Rec.] S. Kieniewicz, Historyk a świadomość narodowa, Warszawa 1982, Zeszyty Historyczne 1983 z. 68 s. 201-207;

[Rec.] Galicja w powstaniu styczniowym. Galicija v vosstanii 1863 goda, red. S. Kieniewicz, I. Miller, Wrocław 1980, Zeitschrift für Ostmitteleuropa-Forschung 1983 z. 3, s. 443-445.

1984

Polish National Liberation Struggles and the Genesis of the Modern Nation. Collected Papers, transl. from the Pol. by Roger A. Clarke, Odense 1982. Rec.: H.H. Hennings, Jahrbücher für Geschichte Osteuropas 1984 z. 4, s. 598-599;

„Le Nord” o konflikcie rosyjsko-polskim i o jego perspektywach, Zeszyty Historyczne 1985 z. 74 , s. 58-66. 
1985

Russian policy towards the Scandinavian countries in 1856-1864, Washington 1985.

1986

[Rec.] K. Kersten, Narodziny systemu władzy. Polska 1943-1948, Paris 1986, Zeszyty Historyczne 1986 z. 77, s. 143-147.

1987

Kraje skandynawskie wobec powstania styczniowego, Zeszyty Historyczne 1987 z. 81, s. 21-33.

1988

The 1863 Polish Uprising and Scandinavia. The Year 1863, the Turning-Point in Russo-Scandinavian Relations, København 1988;

Aleksander II - Michait Gorbaczow, Zeszyty Historyczne 1988, z. 85, s. 40-43;

[Rec.] Polska XIX wieku. Państwo, spoleczeństwo, kultura, pod red. S. Kieniewicza, wyd. 3, Warszawa 1986, Zeszyty Historyczne 1988 z. 84, s. 193-201;

[Rec.] N. Davies, Heart of Europe. A Short Story of Poland, Oxford 1984, Zeitschrift für Ostmitteleuropa-Forschung 1988 z. 1, s. 143-147;

[Rec.] Zarys powstania styczniowego opracowany w Warszawskiej Cytadeli, red. S. Kieniewicz, T. Kopriejewa, L. Szyłow, Wrocław 1986, Zeitschrift für Ostmitteleuropa-Forschung 1988 z. 2, s. 287-292.

1989

Die Rolle des gebildeten Offiziers im Europa des 18. Jahrhunderts. Die Polnische Ritterakademie in den Jahren 1765-1794, Zeitschrift für Ostmitteleuropa-Forschung 1989 z. 1, s. 82-94;

[Rec.] M. Król, Konserwatyści a niepodległość. Studia nad polska myśla konserwatywna XIX wieku, Warszawa 1985, Zeszyty Historyczne 1989 z. 87, s. 204-207;

[Rec.] M. Tymowski, J. Kieniewicz, J. Holzer, Historia Polski, Paris 1986, Zeitschrift für Ostmitteleuropa-Forschung 1989 z. 1, s. 115-118;

[Rec.] M. Tyrowicz, Jan Tyssowski i rewolucja 1846 r. w Krakowie. Dzieje porywu i pokuty, Kraków 1986, Zeitschrift für Ostmitteleuropa-Forschung 1989 z. 3, s. 460—461.

1990

Russia and Denmark 1856-1864: a Chapter of Russian Policy Towards the Scandinavian Countries, transl. from the Polish by R. A. Clarke, Copenhagen 1990. Rec.: S. Kieniewicz, Przegląd Historyczny 1991 z. 2, s. 337-340.

1991

[Rec.] A. Tuszyńska, Rosjanie w Warszawie, Paryż 1990, Zeszyty Historyczne 1991 z. 96, s. 222-225;

[Rec.] Powstanie kościuszkowskie w dokumencie archiwalnym. Wolność, całość i niepodległość 1794, oprac. B. Sobolowa, Warszawa 1985, Zeitschrift für Ostmitteleuropa-Forschung 1991 z. 1, s. 134-136;

[Rec.] H. Florkowska-Franić, Emigracyjna działalność Agatona Gillera po powstaniu styczniowym, Wrocław 1985, Zeitschrift für Ostmitteleuropa-Forschung 1991 z. 1, s. 141-143.

[Rec.] S. Kieniewicz, Dereszewicze 1863, Wrocław 1986, Zeitschrift für OstmitteleuropaForschung 1991 z. 2, s. 297-298.

1992

[Rec.] J. Jedlicki, Jakiej cywilizacji Polacy potrzebują. Studia z dziejów idei i wyobrażeń XIX wieku, Warszawa 1988, Zeitschrift für Ostmitteleuropa-Forschung 1992 z. 3, s. 440-442;

[Rec.] C. Madajczyk, Dramat Katyński, Warszawa 1989, Zeitschrift für OstmitteleuropaForschung 1992 z. 3, s. 449-450.

1993

Memoriat ... do Napoleona z 1807 r., wyd. E. Halicz, Przegląd Historyczny 1993 z. 1, s. 65-67.

Poland's memorandum to the Peace Congress in Rome, November 1891, ed. by E. Halicz, Copenhagen 1993;

[Rec.] Powstanie styczniowe 1863-1864. Wrzenie, bój, Europa, wizje, red. S. Kalembka, Warszawa 1990, Zeitschrift für Ostforschung 1993 z. 2, s. 297-299. 
1994

Aleksander Hercen i sprawa polska w latach posewastopolskiej wiosny (1856-1861), [w:] En slavist i humanismens tegn. Festskrift til Kristine Heltberg, København 1994, s. 117-127;

[Rec.] M. Waldenberg, Kwestie narodowe w Europie Środkowo-Wschodniej. Dzieje, idee, Warszawa 1992, Zeszyty Historyczne 1994 z. 108, s. 209-213;

[Rec.] F. Ramotowska, Narodziny tajemnego państwa polskiego 1859-1862, Warszawa 1990, Zeitschrift für Ostforschung 1994 z. 2, s. 288-290.

1995

[Rec.] T. Pióro, Armia ze skazq. W Wojsku Polskim 1945-1968. (Wspomnienia i refleksje), Warszawa 1994, Zeszyty Historyczne 1995 z. 111, s. 196-201.

1996

[Rec.] H. Batowski, Zachód wobec granic Polski 1920-1949. Niektóre fakty mniej znane, Łódź 1995, Zeszyty Historyczne 1996 z. 116, s. 162-165.

1997

[Rec.] A. Gill, Eine tragische Staatsgrenze. Geschichte der deutsch-polnischen Grenze von 1918-1945, Frankfurt am Main 1997, Zeszyty Historyczne 1997 z. 121, s. 159-162.

1998

[Rec.] J. Tazbir, Polska na zakrętach dziejów, Warszawa 1997, Zeszyty Historyczne 1998 z. 126, s. 190-196;

[Rec.] A. Gill, Freiheitskëmpfe der Polen im 19. Jahrhundert. Erhebungen - Aufstande Revolutionen, Frankfurt am Main 1997, Zeszyty Historyczne 1998 z. 124, s. 195-199;

[Rec.] A. Gill, Eine tragische Staatsgrenze. Geschichte der deutsch-polnischen Grenze von 1918-1945, Frankfurt am Main 1997, Historisk Tidsskrift 1998 z. 1, s. 225-228.

1999

[Rec.] C. W. Smith i jego polscy korespondenci 1861-1870, polska korespondencja z thumaczeniami na duński ze wstępem i przypisami wydali P. Flandrup, K. Heltbergm, Kopenhaga 1997, Zeitschrift für Ostmitteleuropa-Forschung 1999, s. 308-308;

[Rec.] S. Nicieja, Lyczaków - dzielnica za Styksem, Wrocław 1998, Przegląd Historyczny 1999 z. 4 , s. $578-579$.

2001

[Rec.] M. Waldenberg, Narody zależne i mniejszości narodowe w Europie ŚrodkowoWschodniej. Dzieje konfliktów $i$ idei, Warszawa 2000, Przegląd Historyczny 2001 z. 1, s. $130-131$.

2003

[Rec.] M. Zybura, Niemcy w Polsce, Wrocław 2001, Zeszyty Historyczne 2003 z. 143, s. 187-190.

2004

[Rec.] N. Davies, Powstanie '44, Kraków 2004, Zeszyty Historyczne 2004 z. 149, s. 118-120.

2005

[Rec.] D. Beauvois, Trójkąt ukraiński. Szlachta, carat i lud na Wolyniu, Podolu i Kijowszczyźnie 1793-1914, Lublin 2005, Zeszyty Historyczne 2005 z. 154, s. 195-199. 